\title{
Maize yield and soil fertility as influenced by crop rotation and different fertilization regimes
}

\author{
Yueli Wang, Qiang Ma* \\ Institute of Applied Ecology, Chinese Academy of Sciences \\ Shenyang, China \\ *iae_yfxh@sina.com (Corresponding author)
}

\begin{abstract}
In a long-term experiment established in early 1990, the effects of crop rotation and mineral fertilizers were studied on the maize (Zea mays L.) yield and soil fertility. The results indicated that maize yield increased significantly with $\mathrm{N}$ application, and further higher yield was obtained in NP and NPK treatments. The yield averagely increased by $0.69 \mathrm{t} / \mathrm{ha}$, and the yield-increasing effect of crop rotation was more significant in the treatments without fertilizer $N(34.2 \%$ increase rate, averagely). However, the yield-increasing effect of rotation was diminished with balanced nutrient supply, especially for $\mathbf{N}$. Furthermore, yield stability was improved by balanced nutrient and crop rotation application. Compared with monoculture, soil fertility increased after soybean planting to some extent, whereas crop rotation cannot completely overcome nutrient deficiency when the corresponding mineral nutrient was absent. Consequently, mineral nutrient management and crop rotation should be integrated for the sustainable development of agriculture.
\end{abstract}

Index Terms-Crop rotation; Maize; Soil fertility; Sustainable development

\section{INTRODUCTION}

The worldwide agriculture has been undergoing profound changes due to mineral fertilizers application in the last century $[1,2]$. Over application of mineral fertilizers, especially for fertilizer $\mathrm{N}$, has become a serious problem in intensive agricultural regions of China, threatening the environment. In the North China Plain, fertilizer $\mathrm{N}$ application rates ranged from 120 to $730 \mathrm{~kg} / \mathrm{ha}$ for winter wheat, and ranged from 96 to $482 \mathrm{~kg} / \mathrm{ha}$ for summer maize [3]. Because nutrient management shifted to reliance on mineral fertilizers for achieving anticipant high crop yield, many beneficial agricultural strategies were abandoned, such as crop rotation, intercropping and utilization of various organic manures etc. Cereal rotated with legume is an important traditional farming practice to improve crop yield and maintain soil fertility. Studies have proved that crop rotation was favorable for breaking disease, controlling weed, improving soil nutrient and water conditions, etc. [4]. Therefore, researchers believed that crop rotation was an efficient way to decrease the reliance on mineral fertilizer in agriculture [5]. Liaoning province has the longest history of agriculture in Northeastern China. Maize is the main crop and there are about 2.1 million ha of maize field, which account for $55 \%$ of all the arable land. Maize monoculture and soybeanmaize rotation were two major cropping systems of rain-fed dryland. Although rotation was found to offer the better potential for improving cropping practices in the region, farmers prefer to plant continuous maize due to the cultivation customs and high yield of maize.

The aims of the present paper were (i) to evaluate the yieldincreasing effects of crop rotation and fertilization, and (ii) to characterize soil fertility influenced by fertilization and rotation in lower reach of Liaohe River Plain.

\section{MATERIALS AND METHODS}

Experimental site, design and treatments. A long-term field experiment has been conducted since 1990 in the Institute of Applied Ecology, Chinese Academy of Sciences (413' $\mathrm{N}$ latitude, $123^{\circ} 23^{\prime} \mathrm{E}$ longitude). The mean annual temperature is 7.0-8.0 ${ }^{\circ} \mathrm{C}$. Its annual precipitation is about $680 \mathrm{~mm}$. The soil of the experimental field is alfisol soil. The initial properties of the surface soil $(0-20 \mathrm{~cm}$ depth) were shown in table I.

The experiment had 8 treatments: no fertilizer $(\mathrm{CK}), \mathrm{N}, \mathrm{P}$, K, NP, NK, PK, and NPK treatments. Nitrogen, Phosphorus, and Potassium fertilizers were applied at the rates of 150, 25, and $60 \mathrm{~kg} / \mathrm{ha}$ for maize in the form of urea, double superphosphate, and potassium chloride, respectively. All of fertilizers $\mathrm{P}$ and $\mathrm{K}$ and $40 \mathrm{~kg} / \mathrm{ha}$ of fertilizer $\mathrm{N}$ were basalapplied prior to sowing and $110 \mathrm{~kg} / \mathrm{ha}$ of fertilizer $\mathrm{N}$ was topdressed at the stem elongation stage. The same application rates of fertilizers $\mathrm{P}$ and $\mathrm{K}$ were supplied for soybean, whereas the application rate of fertilizer $\mathrm{N}$ was $25 \mathrm{~kg} / \mathrm{ha}$ for soybean. All of the fertilizers $\mathrm{N}, \mathrm{P}$ and $\mathrm{K}$ were basal-applied before sowing in the spring. Each plot area was $162 \mathrm{~m}^{2}$, with a buffer zone of $1.0 \mathrm{~m}$. Initially, in 1990, the experiment was started with a soybean-maize-maize 3-year rotation. Then there were two crop sequences for maize per year that the forecrop was maize or soybean, respectively, namely maize monoculture and soybean-maize rotation. Each treatment consisted of 3 replications. The field was ploughed to a depth of $15-20 \mathrm{~cm}$ by horses in spring and pesticides and fungicide were applied when needed during the growing season. Irrigation and herbicides were not applied and weeds were removed by handhoeing. Crops were harvested manually close to the ground

TABLE I. INITIAL PHYSICAL AND CHEMICAL PROPERTIES OF TEST SOIL

\begin{tabular}{|c|c|c|c|c|c|c|}
\hline Organic matter $(\mathrm{g} / \mathrm{kg})$ & Total nitrogen $(\mathrm{g} / \mathrm{kg})$ & Total P (g/kg) & Total K (g/kg) & Available P (mg/kg) & Available K (mg/kg) & pH \\
\hline 20.9 & 1.13 & 0.44 & 16.4 & 10.6 & 88.0 & 6.5 \\
\hline
\end{tabular}


TABLE II. EFFECT OF FERTILIZATION AND ROTATION ON GRAIN YIELD OF MAIZE

\begin{tabular}{|c|c|c|c|c|c|c|}
\hline \multirow{2}{*}{ Treatments } & \multicolumn{2}{|c|}{ Yield (t/ha) } & \multicolumn{2}{|c|}{ Yield-increasing rate $(\%)$} & \multicolumn{2}{|c|}{ Coefficient of variation (\%) } \\
\hline & Monoculture & Soybean-maize & Monoculture & Soybean-maize & Monoculture & Soybean-maize \\
\hline $\mathrm{CK}$ & $3.302 \mathrm{Aa}$ & $4.494 \mathrm{Ba}$ & - & - & 39.3 & 29.1 \\
\hline $\mathrm{N}$ & $5.641 \mathrm{Ab}$ & $5.866 \mathrm{Abc}$ & 70.85 & 30.53 & 29.1 & 28.9 \\
\hline $\mathrm{P}$ & $3.688 \mathrm{Aa}$ & 4.849Bab & 11.70 & 7.89 & 32.9 & 30.7 \\
\hline $\mathrm{K}$ & $3.438 \mathrm{Aa}$ & $4.493 \mathrm{Ba}$ & 4.12 & -0.03 & 36.5 & 30.3 \\
\hline NP & 6.569Abc & 6.698Acd & 98.96 & 49.02 & 19.6 & 23.2 \\
\hline NK & $6.205 \mathrm{Ab}$ & 6.529Acd & 87.91 & 45.26 & 29.4 & 27.1 \\
\hline $\mathrm{PK}$ & $3.678 \mathrm{Aa}$ & $5.087 \mathrm{Bab}$ & 11.40 & 13.19 & 43.2 & 25.7 \\
\hline NPK & $7.482 \mathrm{Ac}$ & 7.497Ad & 126.60 & 66.36 & 21.3 & 22.6 \\
\hline
\end{tabular}

Capital letters indicate significant differences between different crop rotations within a treatment (row); small letters indicate significant differences among different treatments within a rotation (column), $P \leq 0.05$.

with sickles in autumn, and yield of grain was recorded. Grain samples were oven-dried at $70{ }^{\circ} \mathrm{C}$ to a uniform moisture level and weighed. All harvested biomass was removed from the plots.

\section{Soil sampling and analysis}

Soil samples were collected at depths of $0-20 \mathrm{~cm}$ in the autumn. Five soil samples were collected and mixed to form a composite sample, and three composite samples were collected from each plot. The samples were air dried, ground through a 2 $\mathrm{mm}$ sieve and stored for analysis. Soil Total P (TP), Total K (TK), Alkali-hydrolyzable N (AN), Available P (AP), Available $\mathrm{K}(\mathrm{AK})$ and $\mathrm{pH}$ were determined by the methods: TP (molybdenum method), TK (flame photometer method), AN (alkaline-hydrolyzation method), AP (Olsen method), and AK $\left(1 \mathrm{~mol} \mathrm{~L} \mathrm{~L}^{-1}\right.$ ammonium acetate extraction, flame photometer method), $\mathrm{pH}\left(1: 2.5\right.$, soil/ $\left.\mathrm{H}_{2} \mathrm{O}\right)$. All the methods are described in detail by Lu (2000) [6]. An Elementary vario EL III elemental analyzer was used to determine the Soil Organic Carbon (SOC) and Total $\mathrm{N}$ (TN).

Data analysis. Maize grain yield data was subjected to analysis of variance (ANOVA) followed by Duncan's multiple range test for multiple comparisons of paired means of treatments.

\section{RESULTS}

\section{Yield response}

Fertilizer $\mathrm{N}$ increased maize yield significantly more than $\mathrm{P}$ and $\mathrm{K}$, indicating that $\mathrm{N}$ was the most important nutrient for agricultural production (Table II). The highest yields were observed under NPK treatment in both monoculture and rotation systems. It can also be seen that the yields of maize in monoculture were always lower than in rotation system, especially in the $\mathrm{N}$ absence treatments. Compared with the treatments without $\mathrm{N}$ in monoculture system, yield-increasing rate was averagely $34.2 \%$ due to crop rotation. However, the yield difference between various cropping systems decreased with balanced nutrient supply, especially for $\mathrm{N}$, and the effect of crop rotation on the yield was least under NPK treatment.

Yield stability was improved with crop rotation or balanced nutrient application. The coefficient of variation $(C . V$. was lower in the crop rotation system, with the exception of NP and NPK treatments. The results showed that the effect of crop rotation on yield stability was substantial in the nutrient absence conditions and it was eliminated by the balanced nutrient supply. With the balanced nutrient supply, the yield stability was also improved, and the lowest C.V. was obtained under NP and NPK treatments in both cropping systems. The yield stability improvement could be attributed to the good adaptation of maize to various environments with balanced nutrient application and crop rotation introduced. Therefore, balanced nutrient supply and proper crop rotation should be integrated when the cropping systems were optimized.

\section{Nutrient uptakes and soil nutrients}

Nutrient uptakes were much lower by soybean than maize due to lower biomass of soybean and the N-fixation by legume, leading to more residual nutrients in soil (Fig. 1). The soil nutrients were markedly affected by fertilization, and the nutrients increased with the mineral fertilizers application. The higher available nutrient concentrations of soils were observed in crop rotation system, although the differences were not significant between the different cropping systems, except for Olsen-P in the treatments $\mathrm{N}$ and NK (Table III). It was also important to note, however, that concentration of alkalihydrolyzable $\mathrm{N}$ was higher in the field after sowing soybean, although the application of fertilizer $\mathrm{N}$ was much lower in the field planting soybean $(25 \mathrm{~kg} / \mathrm{ha})$ than the field sowing maize (150 kg/ha), proving the effect of $\mathrm{N}$-fixation legume on soil $\mathrm{N}$ fertility improvement. Nevertheless, crop rotation cannot
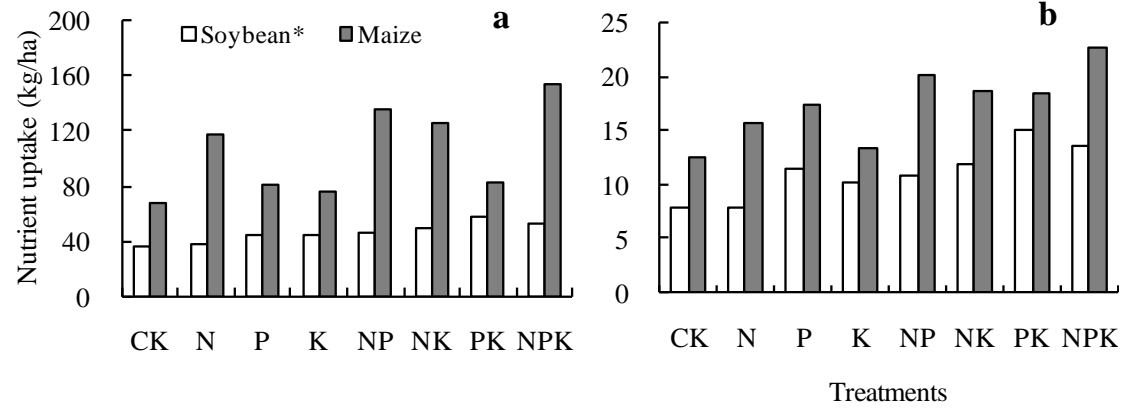

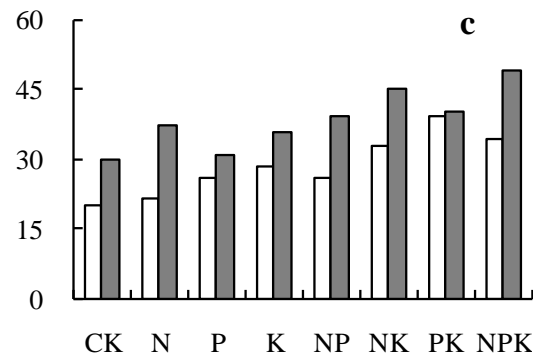

Fig. 1. Nutrient uptakes of crops under different fertilization treatments.

* Considering 2/3 N derived from $\mathrm{N}$-fixation of soybean under conventional fertility regime in this region [7], $\mathrm{N}$ uptake by soybean was $1 / 3$ of total $\mathrm{N}$ harvested in the illustration: $\mathrm{a} . \mathrm{b}$ and $\mathrm{c}$ indicate $\mathrm{N}$. $\mathrm{P}$ and $\mathrm{K}$ untake bv maize. resnectivelv. 
TABLE III. AVAILABLE NUTRIENT CONCENTRATIONS OF SOILS UNDER VARIOUS TREATMENTS AND CROPPING SYSTEMS

\begin{tabular}{|c|c|c|c|c|c|c|}
\hline \multirow{2}{*}{ Treatment } & \multicolumn{2}{|c|}{ Alkali-hydrolyzable N } & \multicolumn{2}{|c|}{ Available $\mathbf{P}$} & \multicolumn{2}{|c|}{ Soil exchangeable $\mathbf{K}$} \\
\hline & After maize & After soybean & After maize & After soybean & After maize & After soybean \\
\hline $\mathrm{CK}$ & $81.13 \mathrm{Ab}$ & $84.35 \mathrm{Ab}$ & $4.19 \mathrm{Bd}$ & $4.45 \mathrm{Ad}$ & $74.35 \mathrm{Ac}$ & $75.39 \mathrm{Ac}$ \\
\hline $\mathrm{N}$ & $94.54 \mathrm{Aa}$ & $96.80 \mathrm{Aa}$ & $3.96 \mathrm{Be}$ & $4.26 \mathrm{Ad}$ & $73.73 \mathrm{Ac}$ & $75.43 \mathrm{Ac}$ \\
\hline $\mathrm{P}$ & $88.56 \mathrm{Aab}$ & $88.20 \mathrm{Ab}$ & $13.36 \mathrm{Aa}$ & $13.70 \mathrm{Aa}$ & $78.00 \mathrm{Ac}$ & $79.54 \mathrm{Ab}$ \\
\hline $\mathrm{K}$ & $85.50 \mathrm{Ab}$ & $87.91 \mathrm{Ab}$ & $5.41 \mathrm{Ad}$ & $5.68 \mathrm{Ad}$ & $93.90 \mathrm{Aa}$ & $93.74 \mathrm{Aa}$ \\
\hline NP & $95.37 \mathrm{Aa}$ & $97.05 \mathrm{Aa}$ & $10.23 \mathrm{Ab}$ & $11.00 \mathrm{Aab}$ & $74.77 \mathrm{Ac}$ & $75.84 \mathrm{Ac}$ \\
\hline NK & $97.42 \mathrm{Aa}$ & $99.61 \mathrm{Aa}$ & $7.02 \mathrm{Bc}$ & $7.51 \mathrm{Ac}$ & $95.40 \mathrm{Aa}$ & $96.46 \mathrm{Aa}$ \\
\hline PK & $89.27 \mathrm{Aab}$ & $93.57 \mathrm{Aa}$ & $14.16 \mathrm{Aa}$ & $14.28 \mathrm{Aa}$ & $93.26 \mathrm{Aa}$ & $93.15 \mathrm{Aa}$ \\
\hline NPK & $94.19 \mathrm{Aa}$ & $95.01 \mathrm{Aa}$ & $10.17 \mathrm{Ab}$ & $10.67 \mathrm{Ab}$ & $87.19 \mathrm{Ab}$ & $88.89 \mathrm{Aab}$ \\
\hline
\end{tabular}

Capital letters indicate significant differences between different crop rotations within a treatment (row); small letters indicate significant differences among different treatments within a rotation (column), $P<0.05$.

completely overcome nutrient deficiency when the corresponding mineral nutrient was absent [8]. Karlen et al. (1994) also pointed out that the rotation effect was a combined

effect of multiple factors [4], including weed control, pest infestations reduction, soil physical properties improvement and soil bio-fertility increase, etc. Thereby, the balanced mineral nutrient application should not be neglected to guarantee high yield in the intensive agriculture systems.

Contribution of fertilization to yield with different stubble

As showed in Fig. 2, with balanced mineral fertilizers application and crop rotation, yield-increasing rate as well as contribution rate of fertilization was increased significantly [9]. The contribution rates of mineral fertilizers to maize yield ranged from $4.0 \%$ to $55.9 \%$, and the highest value was obtained in the treatment NPK. The contribution rate increased obviously with fertilizer $\mathrm{N}$ application, especially combined with fertilizer P. However, the contribution rates of fertilizer $\mathrm{P}$ and $\mathrm{K}$ were very low to increasing yield, especially for fertilizer $\mathrm{K}$. The contribution rate of mineral fertilizer, on average, was $31.2 \%$ in maize continuous cropping system. In crop rotation system, the contribution of mineral fertilizer to increasing yield was enhanced significantly, and ranged from $26.5 \%$ to $56 \%$. The magnitude of the contribution increase was much higher in the treatments with unbalanced fertilization. For example, the contribution rates of fertilizer $\mathrm{P}$ and $\mathrm{K}$ were $10.5 \%$ and $4.0 \%$ in the continuous cropping system, respectively, whereas the corresponding values were $31.9 \%$ and $26.5 \%$, respectively. This also provided the evidence of the importance of crop rotation, especially in the nutrient of nitrogen absence conditions. The contribution rates of mineral fertilizers were $41.9 \%$ averagely in crop rotation system, and higher than that in the continuous cropping system, indicating that the contribution of crop rotation was substantial to yield increase. Cereals rotated with legume should be paid more attention in the region, where the fertilizer $\mathrm{N}$ supplied deficiently. On the other hand, the contribution of crop rotation on yield increase was eliminated with fertilizer $\mathrm{N}$ application, and this can be explained that the effect of crop rotation was mainly due to the capacity of soil nitrogen supply improvement in the study region. But the mineral fertilizers were indispensable for sustainable development of agriculture in this region.

\section{CONCLUSIONS}

The results suggest that fertilizer $\mathrm{N}, \mathrm{P}$ and $\mathrm{K}$ were utilized more efficiently in fully balanced fertilizer treatments than in imbalanced treatments. Yield-increasing effect of crop rotation was substantial and partially overcome the absence of mineral nutrient inputs, whereas the effect was eliminated with fertilizer $\mathrm{N}$ application, indicating that the yield-increasing effect of crop rotation was mainly attributed to the soil nitrogen level improvement. The soil fertility was enhanced after soybean planting due to the more residual nutrients and $\mathrm{N}$ fixation by soybean, although the differences were not significant. Yield stability was improved with both balanced nutrient supply and crop rotation application. For agriculture sustainable development, the balanced nutrient application and crop rotation should be taken into account when the cropping system was established or optimized.

\section{ACKNOWLEDGMENT}

This work was financially supported by National Key Technology R \& D Program (No. 2012BAD05B06) and National Natural Science Foundation of China (No. 31000206).

\section{REFERENCES}

[1] C. C. Mitchell, R. L. Westerman, J. R. Brown and T. R. Peck, "Overview of long-term agronomic research," Agron. J., 1991, 83, 24-29.

[2] Q. Chen, X. S. Zhang, H. Y. Zhang, P. Christie, X. L. Li, D. Horlacher and H. P. Liebig, "Evaluation of current fertilizer practice and soil fertility in vegetable production in the Beijing region," Nutr. Cycl. Agroecosyst., 2004, 69, 51-58.

[3] Y. X. Miao, B. A. Stewart and F. S. Zhang, "Long-term experiments for sustainable nutrient management in China. A review," Agron. Sustain. Dev., 2011, 31, 397-414.

[4] D. L. Karlen, G. E. Varvel, D. G. Bullock and R. M. Cruse, "Crop rotations for the 21st-century," Adv. Agron., 1994, 53, 145. 


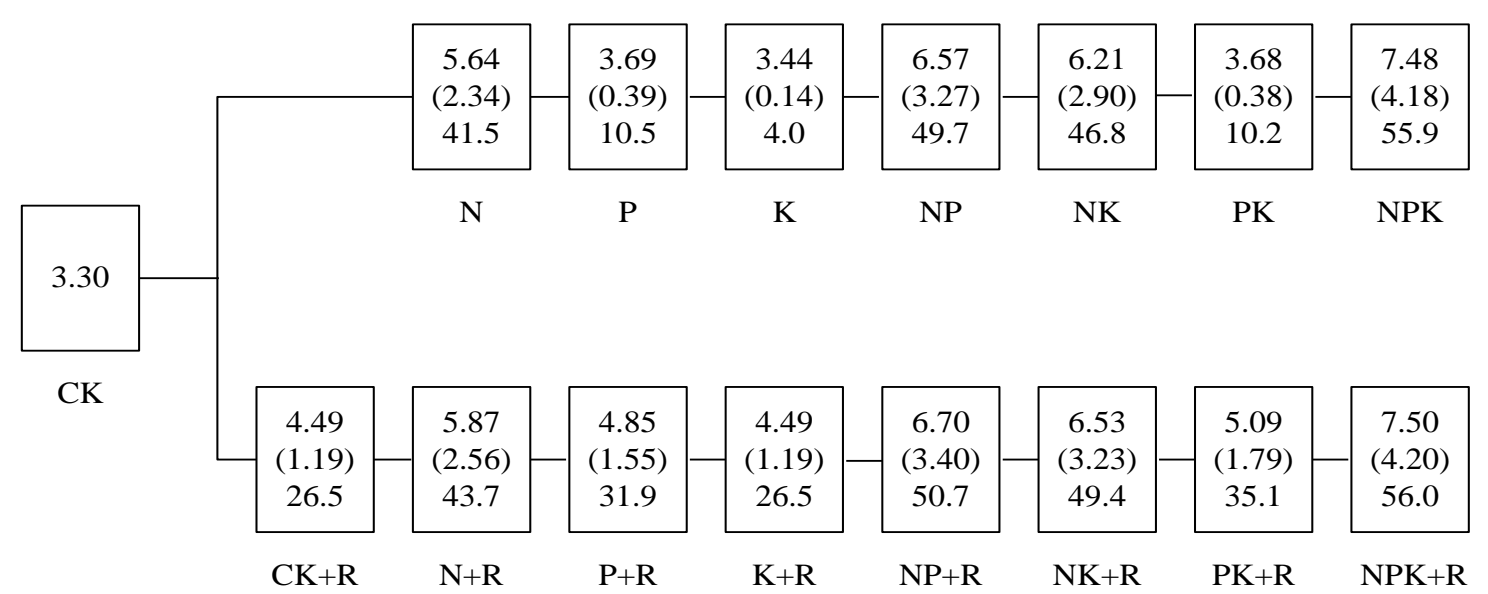

Fig. 2. Contributions of mineral fertilizers and crop rotation to increment of maize yield.

Figure in the first row of each textbox represent yield $(\mathrm{t} / \mathrm{ha})$; figure in the second row represent increment of yield, and figure in the third row represent contribution rate of fertilization $(\%)$. The treatments under crop rotation were expressed as treatment $+\mathrm{R}$.

[5] G. E. Varvel, "Crop rotation and nitrogen effects on normalized grain yields in a long-term study," Agron. J., 2000, 92, 938-941.

[6] R. K. Lu, "Analytical methods for soil and agricultural chemistry," China Agricultural Science and Technology Press, Beijing, 2000.

[7] S. M. Shen, "Soil fertility in China," Chinese Agricultural Press, Beijing, 1998.

[8] W. E. Riedell, T. E. Schumacher, S. A. Clay, M. M. Ellsbury,
M. Pravecek and P. D. Evenson, "Corn and soil fertility responses to crop rotation with low, medium, or high inputs," Crop Sci., 1998, 38, 427-433.

[9] S. M. Shen, W. T. Yu, X. Chen, L. Zhang, H. X. Liu, D. L. Wang, K. R. Wang, W. J. Zhou, X. L. Xie, "Contribution of fertilization development in food production and its geographic differentiation,” Chin. J. App. Ecol., 1998, 9, 386-390. 